\title{
A cultural identity perspective of entrepreneurial performance of small firms
}

Eniola, Anthony Abiodun

Landmark University, Kwara State, Nigeria (tony42003@yahoo.co.uk)

Ojo, Olubunmi Raphael

Millennium College of Health Technology, Ondo State, Nigeria (Olubunmiojo14@gmail.com)

Ajala, Abosede Bamidele

Achievers University, Owo, Nigeria (abosedebamidele55@gmail.com)

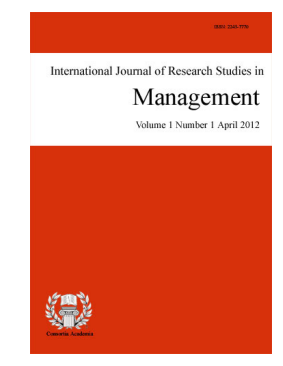

ISSN: $2243-7770$

Online ISSN: 2243-7789

OPEN ACCESS

\section{Abstract}

The study investigates the effects of cultural identity on entrepreneurial performance of small and medium-scale enterprises (SMEs) in Delta State, Niger Delta region of Nigeria. The study drew on the family orientation theory and education incubation theory as foundation for examining this relationship. The study applied a cross-sectional survey approach using 300 SMEs in Delta State who responded to a structured questionnaire. The Spearman's rank correlation coefficient was used in analyzing the hypotheses. The analyses indicate that family structure and communal spirit have a positive and significant relationship with entrepreneurial performance. However, individualism orientation has a weak but positive relationship with profitability and survival. The study concluded that entrepreneurs' cultural identities enhance entrepreneurial performance-especially SMEs in Delta State. It is recommended that SMEs could raise entrepreneurial performance by adopting key antecedents of cultural identity - family structure, communal spirit and individualism orientation - from successful cultural groups.

Keywords: SMEs; entrepreneurial performance; cultural orientation; cultural identity; Nigeria 


\section{A cultural identity perspective of entrepreneurial performance of small firms}

\section{Introduction}

Generally, national culture has been found to influence peoples' behavior and provides an important tool for explaining individual behavior despite the complexity of cultural behavior (Imm Ng, Anne Lee, \& Soutar, 2007). The cultural environment encompasses values and norms which provide foundations and orientation towards achieving entrepreneurial success. This view has been used to explain levels of entrepreneurial success ascribed to cultural groups (Thomas \& Mueller, 2000). Hofstede (2002) explained the importance of his five cultural dimensions which are very relevant for understanding the effects of culture on business practices. Cultural background and identity have been touted as key success factors in growing and achieving entrepreneurial success. According to Rogoff and Heck (2003), to ignore cultural identities such as family structure, communal spirit, and cultural orientation upon which entrepreneurship emerges is synonymous with a myopic view of small and medium scale enterprises (SMEs). Consequently, a growing number of scholarly efforts have been made to improve understanding of why some ethnic groups are more entrepreneurial than others. For instance, Harrison and Huntington (2006), suggest that the differences in SMEs' performance could be attributed to differences in cultural orientation, values, and beliefs. The orientation of some cultures (like the Koreans and Chinese) inspires innovation and entrepreneurial success by developing knowledge capital (Oluwatobi, Olurinola, Alege, \& Ogundipe, 2018).

However, majority of the existing studies on the influence of culture on business performance focused on developed countries - thereby, leaving the African, especially the Nigerian experience unexplored. Notable exceptions to this assertion are (Akpor-Robaro, 2012; Onodugo \& Onodugo, 2015). Onodugo and Onodugo (2015) evaluated the impact of socio-cultural factors in entrepreneurial development in Nigeria. Findings revealed that factors such as economic conditions, socio-cultural forces, political and legal forces, as well as, technological innovations directly influence entrepreneurial development in Nigeria. Furthermore, Akanmu, Alhaji, Kowo Solomon Akpoviroro, and Ajani (2018) examined the effect of cultural orientation on entrepreneurial cluster initiatives. The results show that culture of the people greatly determines the entrepreneurial cluster initiatives and performance.

The studies referred to above focused on northern Nigeria without covering the southern parts of the country known for their entrepreneurial zeal despite infrastructural and environmental challenges (Gershon \& Ezurum, 2017). The foregoing, therefore, shows that there is limited understanding of how cultural identity dimensions influence entrepreneurship including the profitability and survival of SMEs in Nigeria. This study seeks to bridge the gap by investigating the effect of three dimensions of cultural identity- family structure, communal spirit and individualism orientation - on entrepreneurial performance of SMEs. So far, it is the first scholarly attempt to examine the influence of culture on the entrepreneurial performance of SMEs in southern Nigeria-focusing on Delta State in particular. Delta State is in the south-south geopolitical region of Nigeria which has abundant energy resources and International Oil Companies (IOCs). The existence of IOCs in the city/region has transformed it into a hub of commercial activities which attract services and manufacturing firms, as well as, SMEs owned by people from different cultures.

\subsection{Statement of the problem and research objectives}

Entrepreneurial performance is an important determinant of economic growth and development which requires the attention of governments (at all levels) and international organizations (Liang \& Dunn, 2010). From an industry perspective, SMEs in Nigeria have witnessed a steady decline in profit and growth especially as a result of infrastructural deficit which generally poses a serious threat to business survival. There is, therefore, an observed increase in the failure of SMEs (Chrisman, Chua, Pearson, \& Barnett, 2012; Eniola, 2018; World Bank, 
2014). Another school of thought proposes that other environmental factors such as cultural identity could affect the business survival of SMEs. Could it be said that people from certain cultural backgrounds tend to succeed more as entrepreneurs than others? Perhaps Cultural identity and orientation could make the difference in SMEs success or failure. However scholarly works point to the fact that cultural identity can play a major role in determining SMEs performance (Rogoff \& Heck, 2003; Thomas \& Mueller, 2000).

Having discussed the importance of cultural identity in impacting entrepreneurial performance; an evaluation of this importance as regards to SMEs in Nigeria is paramount in this study. Therefore, this study investigated the relationship between cultural identity and entrepreneurial performance of SMEs in Delta State. While seeking solution to the above problem statement, the study achieved the predetermined research objectives. Specifically, findings revealed that: first, there exists a positive and significant relationship between family structure and entrepreneurial performance of SMEs in Delta State. Second, findings revealed the existence of a positive relationship between communal spirit and entrepreneurial performance of SMEs in Delta State. Third, evidence showed that a weak but positive relationship between individualism orientation and entrepreneurial performance of SMEs in Delta State.

The remaining part of this paper is organized as follows: review of relevant literature; methodology employed in carrying out the study; analysis of data and discussion of findings. The last section presents the conclusion and recommendations made in the light of the study outcome.

\section{Literature review}

\subsection{Theoretical foundation}

The theory upon which the present study was anchored is the family orientation theory and educational inclination theory. The family orientation theory is of the view that factors such as family background, structure, and orientation are determinants for entrepreneurial characteristics and the emergence of entrepreneurs. The theory posits that the family has a role to play in building entrepreneurial attitude and character (Kuratko \& Hodgetts, 2001). The theory further emphasized that values and norms of the family of an entrepreneur can go a long way to developing entrepreneurial personality and character (Kellermanns, Eddleston, Barnett, \& Pearson, 2008). These propositions are not far from the truth because the family structure and values has a great impact on how an entrepreneur manages his or her business venture. According to Van De Ven (1993), family factors are strong enough to determine entrepreneurial success.

Secondly, the educational incubation theory posits that knowledge creation and new orientation through educational advancement is the key to building entrepreneurial character and attitude. According to Ahmed, Chandran, and Klobas (2017); Block and Stumpf (1990), it is the belief that people with high level of education tend to produce more successful entrepreneurs than people with low education. This is evidenced in the comparison between the less developed countries that are less educated and developed countries that are more educated; and this arguably reflects on entrepreneurial development in the advanced world.

\subsection{Concept of cultural identity}

The concept of cultural identity has been explored by many scholars who advanced various definitions of the concept. For instance, Fong and Chuang (2004) defined the concept as the identification with particular group based on some key cultural categories which includes educational background, language, norms, traditions, heritage, norms and customs. Jameson (2007) sees the concept as a projection through the process of sharing collective knowledge. The author further stated that cultural identity is complex and multifaceted as individuals typically affiliate with more than one cultural group. Also, Miike (2002) asserts that cultural identity is constantly enacted negotiated, maintained, and challenged through communicative practices. 
According to Kim (2007), the concept of cultural identity could be explained from both family and cultural dimensions of an individual's identity and how people perceive this identity. Ibrahim and Heuer (2013) state that cultural identity in reality is multidimensional and this shows that contemporary thinking on cultural identity has moved from single concept of identity to intersections and multi-dimension of identity. This paradigm shift is particularly relevant to counseling and psychotherapy. Hofstede (2001) further mentioned that currently scholars are beginning to evaluate cultural identity in terms of why people from a particular ethnic group do better in terms of entrepreneurship than others depending on the kind of business and other key government policies. The author stated that cultural identity is largely responsible with respect to why people from a particular ethnicity strive more entrepreneurially than others in the same country.

\subsection{Entrepreneurial performance}

Literature on entrepreneurial performance suggests that there is no consensus as to performance indices, consequently, a wide variety of entrepreneurial performance measures exist (Eniola \& Entebang, 2015; Wiklund \& Shepherd, 2005). According to Eniola and Entebang (2015), measures of entrepreneurial performance can be categorized into two namely objective and subjective measures. Similarly; Combs, Russell Crook, and Shook (2005), measured entrepreneurial performance in terms of financial and non-financial measures. The authors stated that studies that use only one dimension or a narrow range of performance indicators may produce misleading results. With respect to the above argument, the fundamental question arises as to what should be the appropriate indices to measure entrepreneurial performance. Chandler and Hanks (1993) assert that financial measures are typically derived from or related to financial accounts found in the entrepreneurial profit and loss statement or balance sheet. On the other hand, non-financial measures are measures not found in the firm's charts of financial account, such as customer loyalty, satisfaction, customer endorsement or referral. The author went ahead to define entrepreneurial performance as the process of measuring an entrepreneur's progress in terms of sales volume profitability, and consumer satisfaction. It is however important to add that before a realistic evaluation can be reached; the entrepreneur's progress must be compared with stated objectives and goal.

\subsection{Cultural identity and entrepreneurial performance}

The relationship between cultural identity and entrepreneurial performance has received considerable attention in both cultural and entrepreneurial literature over the last two decades (Covin, Green, \& Slevin, 2006). Studies have also proven a strong association between both variables (Shane \& Venkataraman, 2000; Swierczek $\&$ Ha, 2003). They are of the view that, cultural identity has a significant influence in shaping entrepreneurs' attitude, commitment that leads to business success. Peppas, Yu, Zhang, and Peppas (2017), examined whether Chinese, Danish and American students shared similar beliefs regarding ethics in business. The study highlights significant attitudinal differences in the three groups and relevant findings about how cultures affect business ethics - by extension business performance. Rao (2009) conducted a study investigating the impact of national culture on staffing in Latin America by examining how modern and emerging trends such as e-recruitment have diffused within such cultures. Traditional recruitment methods such as internal recruitment, personal references, and succession planning, psychometric tests were found to still be associated the cultural dimensions of these countries. Below are dimensions used in conceptualizing cultural identity in relation to entrepreneurial performance:

Family structure and entrepreneurial performance - One important characteristic that shapes entrepreneurial behavior is family structure; with the entrepreneur being a creation of the basic unit of socialization which is the family, it is an essential influence on his general attitude towards everything including business and lifestyle (Gibb, 1996). According to Mokomane (2012), family structure plays a role in providing access to funds and information that could beneficial to the entrepreneur within the family. It also plays the role of orientation as the entrepreneur can hardly ignore family values in managing the business. Aldrich and Cliff (2003), stated that entrepreneurs are inseparably linked to their families and rely on family values in pursuing their entrepreneurial endeavors. 
Moreover, a substantial body of research confirmed that the family into which a person was born and nurtured has some advantage and disadvantages that subsequently influence their socio-economic, emotional, and entrepreneurial capabilities (Barnett, Eddleston, \& Kellermanns, 2009; Bjursell \& Bäckvall, 2011; Harknett, 2005). Barnett et al. (2009), for instance; argued that persons from core traditional family structure had lower risk of dropping out of school and had better adult outcomes. Harknett (2005), argued that persons living with their biological parents has the benefit of shared care and economic resources; and are likely to have better opportunity to fulfill entrepreneurial dreams relative to persons living with non-biological parents. Furthermore, Bjursell and Bäckvall (2011) in their study found that polygamous family tends to do better in business due to the pursuit self-sustenance and independence. This was however debunked by Aldrich and Cliff (2003), when they argued that persons habited in a monotonous family enjoys the luxury of care, better groomed and appear to do better in business.

Consequently, the reviewed studies agree that family structure has a relationship with entrepreneurial success. In the light of the foregoing, the following hypotheses are considered:

$>\mathrm{H}_{01}$ : Family structure has no significant relationship with the profitability of SMEs in Delta State

> $\mathrm{H}_{02}$ : Family structure has no significant relationship with the survival of SMEs in Delta State

Communal spirit and entrepreneurial performance - Nigeria being a multi-ethnic and multi-lingual state has from time immemorial practiced a policy of communalism or as many will term collectivism. Issues of national or societal needs were approach collectively. Hence, the communal approach to solving problems has implications on entrepreneurial behavior. According to Utomi (2000), communalism present the difficult to accumulate sufficient funds or capital to invest in business as Nigerians in their tendencies to support other members of the community in several ways. The authors stated that without investment in new or existing business entrepreneurial development may be hampered. He finally stated that this kind of cultural trait discourages savings.

Constantly to the above claim, Ajekwu (2017), in his study on the nexus between communal spirit and entrepreneurial role in building mutual trust and benefit; the author stated that mutual trust is what enables entrepreneur leverage on established relationship with stakeholders, particularly employees and suppliers with a view to achieving stated objectives. The author has it that a strong relationship exist between communal spirit and entrepreneurial performance. Hence, the following hypotheses are testable:

$>\mathrm{H}_{03}$ : Communal spirit has no significant relationship with the profitability of SMEs in Delta State

> $\mathrm{H}_{04}$ : Communal spirit has no significant relationship with the survival of SMEs in Delta State

Individualism orientation and entrepreneurial performance - Individualism orientation refers to the extent to which people prefer to do things as individuals rather than members of a group (Deakins \& Freel, 2012). Hofstede (2006) suggested that GLOBE research has only complemented his five cultural dimensions by expanding it to eighteen. Individualism has also continued to feature with a high degree of correlation with such factors as GNP/Capita while the questions rose in GLOBE closely resembles his Hofstede's original model. Haapaniemi and Mäkinen (2008) focused on the relationship between national cultural dimensions and national innovation adoption in the context of national wealth, population density and illiteracy rate. The study also adopted Hofstede's five cultural dimensions and found individualism having the highest significant influence on the takeoff of technological innovation adoption. $\mathrm{Ng}$ et al (2006) provided an alternative framework for measuring cultural distance by adapting the Hofstede's and Schwartz's cultural framework. The study found a negative relationship between analysis of the cultural distance score of 23 countries and international trade whereas cultural distance measured by Schwartz's model seemed the most appropriate. Javidan, House, Dorfman, Hanges, and Sully de Luque (2006), responded to a critique of GLOBE research by Hofstede (2006) by explaining that the five cultural dimensions and their interpretation on employee reaction and organizational 
Eniola, A. A., Ojo, O. R., \& Ajala, A. B.

culture are flawed as it is not an action based research whereas the GLOBE research was carried out by over 160 research from different parts of the world.

According to Gibb (1987), extreme individualism mentality possesses preference to act independently as against doing things connectivity. The author stressed that individualistic culture is a society which is character by personal goals and achievement, and a rational assessment of both the beneficial and detrimental aspects of relationship with others. The important point here is to evaluate how this orientation affects entrepreneurial activities and business growth. With respect to the above, scholars have divergent views based on their research findings. While, Fong and Chuang (2004) considered cultural identity and entrepreneur development arguing that entrepreneurs with individualism orientation tend to single-handedly grow enterprise with a great zeal of personal motivation and hard work. Findings of the study showed that individualism orientation has a strong correlation with entrepreneurial growth.

On the contrary, Kim (2007), argued that individualism orientation is a bottleneck to entrepreneurial success. He stated that individualism as both cultural and business philosophies do not promote group cohesion and as such may not be a good business orientation. This is in view of the fact that, for an entrepreneur to survive, stakeholders must work and think like a team especially at different levels of management. He finally stated that an entrepreneur must see the business enterprise as a group of persons with common goal. The essence of this study is to investigate the effect of cultural identity on people's preference for entrepreneurship and their performance especially as observed in a cultural setting in Nigeria. It is against this backdrop, it is hypothesized as follows:

$>\mathrm{H}_{05}:$ Individualism orientation has no significant relationship with the profitability of SMEs.

$>\mathrm{H}_{06}:$ Individualism orientation has no significant relationship with the survival of SMEs.

In sum, the review of literature highlights significant gaps that justify this study in Nigeria where many SMEs are challenged by socio-economic and environmental factors (Ejemeyovwi, Obindah, \& Doyah, 2018). Furthermore, Figure 1 shows the framework adopted from existing literature for the study.

Figure 1: Operational Framework of Cultural Identity andEntrepreneurial Performance

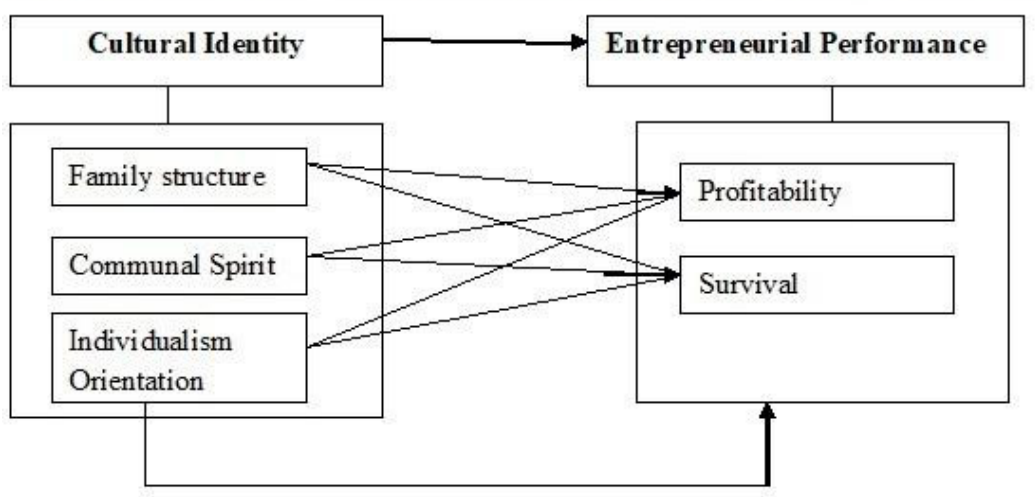

Source: Authors' Extraction from Review ed Literature, 2018

\section{Research methodology}

\subsection{Research design}

Given the fact that the present study investigates owners of SMEs who are human beings without a total control or manipulation of study subjects; and that respondents are located within a specific geographical area, 
hence cross-sectional survey design was adopted in accessing study subjects. Study population constitutes owners of SMEs in Delta State. Furthermore, a total of three hundred SMEs were conveniently selected due to inability to ascertain the exact number of SMEs in the region.

More so, the study adopted both the opened-ended and close-ended type of questionnaire in obtaining primary data. However; journals, internet publication, magazines, among others were secondary sources of data. In addition, while expert juries were used to validate the research instrument, Cronbach Alpha test was adopted in testing the extent to which the instrument can be relied upon and all the dimensions were reliable at .80 and above. Finally, Spearman's Rank Correlation Coefficient was used in testing various hypotheses as proposed in the study.

\subsection{Operational measures of the variables}

The independent variable, Cultural Identity was measured using Family structure, communal spirit and Individualism orientation. These dimensions are further operationalized as shown in Table 1. The dependent variable, Entrepreneurial performance was further measured using profitability and survival which are also operationalized as presented in Table 1.

\section{Table 1}

Operational measures of the criterion and predictor variables

\begin{tabular}{|c|c|}
\hline Code & Cultural Identity \\
\hline & Family Structure \\
\hline FS1 & Entrepreneurs form core traditional families have better business outcome \\
\hline FS2 & Entrepreneurs that were groomed by biological parent are perceived not to succeed in the long-run \\
\hline FS3 & Family core values play an important role in achieving entrepreneurial success \\
\hline \multirow[t]{3}{*}{ FS4 } & Entrepreneurial profitability is linked with family orientation \\
\hline & Source: (Barnett et al., 2009; Harknett, 2005) \\
\hline & Communal Spirit \\
\hline CS1 & Mutual trust plays a vital role in influencing entrepreneurial success \\
\hline $\mathrm{CS} 2$ & Building and leveraging on relationship is an important ingredient in enhancing profitability \\
\hline CS3 & Doing things together all the time does not encourage individual risk in entrepreneurship \\
\hline \multirow[t]{3}{*}{ CS4 } & Collectivism does not encourage individual perseverance \\
\hline & Source: (Ajekwu, 2017; Utomi, 2000) \\
\hline & Individualism Orientation \\
\hline IO1 & Individual zeal and encouragement drives entrepreneurial growth \\
\hline IO2 & Personal motivation and hard work is critical in growing an enterprise \\
\hline IO3 & Preference to make key business decision independently can hamper entrepreneurial growth \\
\hline \multirow[t]{3}{*}{ IO4 } & Individualism cultures do not promote group co-existence in business and may not in turn lead to failure \\
\hline & Source: (Fong \& Chuang, 2004; Gibb, 1987; Kim, 2007) \\
\hline & Entrepreneurial Performance Profitability \\
\hline P1 & An enhanced profit margin is achieved with cost reduction \\
\hline $\mathrm{P} 2$ & Increase in investment will result to enhanced profit \\
\hline P3 & Entrepreneurial R.O.I is a function of individual motivation \\
\hline \multirow[t]{3}{*}{ P4 } & Individual hard work may result to increase in sales volume \\
\hline & Source: (Ezirim, 2004; Fong \& Chuang, 2004) \\
\hline & Survival \\
\hline S1 & Sustainable entrepreneurial growth is linked to a family values \\
\hline S2 & Mutual trust among stakeholders can result to long-run performance \\
\hline S3 & $\begin{array}{l}\text { With the application individual zeal and perseverance an enterprise can remain in business for relatively } \\
\text { long period of time }\end{array}$ \\
\hline S4 & $\begin{array}{l}\text { An enterprise can stay competitive where important decisions are collectively arrived at } \\
\text { Source: (Bjursell \& Bäckvall, 2011; Harknett, 2005) }\end{array}$ \\
\hline
\end{tabular}

The survey research data was generated using a 5-point Likert scale instrument which ran from "strongly agreed to strongly disagreed" indicating the most preferred option to the least preferred option. 


\subsection{Data analysis and testing of hypotheses}

Table 2 shows that out of 300 copies of questionnaire distributed, only 192 copies were returned. However distributed copies were subjected to data treatment and only 180 copies were found useful for the study.

\section{Table 2}

Questionnaire administration

\begin{tabular}{lcc}
\hline \multicolumn{1}{c}{ Details } & Frequency & Percentage \\
\hline Distributed copies & 300 & 100 \\
Returned copies & 192 & 64 \\
Used copies & 180 & 94 \\
Unused copies & 12 & 6 \\
\hline
\end{tabular}

Source. Survey Data, 2019.

\subsection{Decision rules for Testing of Hypotheses}

Accept the null hypotheses (Ho) and reject the alternate hypotheses (Ha) if the significant probability value $p>0.05$, that is, no significant coefficient exist. Reject the null hypotheses (Ho) and accept the alternate hypotheses (Ha) if the significant probability value $p<0.05$. The strength of the relationship is decided thus; -0.1 to -0.4 (weak negative relationship), -0.5 to -0.7 (moderate negative relationship), -0.8 to -0.9 (strong negative relationship), -1 (perfect negative relationship); +0.1 to +0.4 (weak positive relationship), +0.5 to +0.7 (moderate positive relationship), +0.8 to +0.9 (strong positive relationship), +1 (perfect positive relationship).

\section{Hypothesis One}

$\mathrm{H}_{01}$ : Family structure has no significant relationship with the profitability of SMEs in Delta State

The results of the Spearman correlation shows that there was a significant positive association between family structure and probability value, $(\mathrm{rs}(180)=.84, p<.05)$. Therefore, the null hypothesis is rejected, and the alternate hypothesis is accepted; $\mathrm{H}_{1}$ is accepted.

\section{Hypothesis Two}

$\mathrm{H}_{02}$ : Family structure has no significant relationship with the survival of SMEs in Delta State

The results reveals that the Spearman correlation shows a significant positive relationship between family structure and survival of SMEs, $(\mathrm{rs}(180)=.79, p<.05)$. Therefore, the null hypothesis is rejected, and the alternate hypothesis is accepted; $\mathrm{H}_{2}$ is accepted.

\section{Hypothesis Three}

$\mathrm{H}_{03}$ : Communal spirit has no significant relationship with the profitability of SMEs in Delta State

The results indicates that the Spearman correlation shows a significant positive relationship between communal spirit and profitability value of SMEs, $(\mathrm{rs}(180)=.93, p<.05)$. Therefore, the null hypothesis is rejected, and the alternate hypothesis is accepted; $\mathrm{H}_{3}$ is accepted.

\section{Hypothesis Four}

$\mathrm{H}_{04}$ : Communal spirit has no significant relationship with the survival of SMEs in Delta State

The results reveals that the Spearman correlation shows a significant positive relationship between communal spirit and survival of SMEs, $(\mathrm{rs}(180)=.88, p<.05)$. Therefore, the null hypothesis is rejected, and the alternate hypothesis is accepted; $\mathrm{H}_{4}$ is accepted. 


\section{Hypothesis Five}

$\mathbf{H}_{05}$ : Individualism orientation has no significant relationship with the profitability of SMEs

The result reveals that the Spearman correlation shows a positive but weak relationship between Individualism Orientation and Profitability of SME, $(\mathrm{rs}(180)=.42, p>.05)$. Therefore, the null hypothesis is accepted, and the alternate hypothesis is rejected; $\mathrm{H}_{5}$ is rejected.

\section{Hypothesis Six}

$\mathbf{H}_{\mathbf{0 6}}$ : Individualism orientation has no significant relationship with the survival of SMEs

The result indicates that the Spearman correlation shows a positive but weak relationship between Individualism Orientation and Profitability of SME, $(\operatorname{rs}(180)=.44, p>.05)$. Therefore, the null hypothesis is accepted, and the alternate hypothesis is rejected; $\mathrm{H}_{6}$ is rejected.

Table 4 depicts a summary of the hypotheses testing of the study for a clearer understanding of the results.

\section{Table 4}

Summary of the correlation of dimensions for cultural identity and entrepreneurial performance $(N=180)$

\begin{tabular}{|c|c|c|c|c|c|c|}
\hline Items & Statistics & (1) & (2) & (3) & (4) & $(5)$ \\
\hline \multirow[t]{2}{*}{ Family Structure (1) } & Correlation Coefficient & 1 & & & & \\
\hline & Sig. (2-tailed) & - & & & & \\
\hline \multirow[t]{2}{*}{ Communal Spirit (2) } & Correlation Coefficient & $* *$ & 1 & & & \\
\hline & Sig. (2-tailed) & . & - & & & \\
\hline \multirow[t]{2}{*}{ Individualism Orientation (3) } & Correlation Coefficient & $* *$ & $* *$ & 1 & & \\
\hline & Sig. (2-tailed) & .00 & .00 & - & & \\
\hline \multirow[t]{2}{*}{ Profitability (4) } & Correlation Coefficient & $.84 * *$ & $.94 * *$ & $.93 * *$ & 1 & \\
\hline & Sig. (2-tailed) & .00 & .00 & .00 & - & \\
\hline \multirow[t]{2}{*}{ Survival (5) } & Correlation Coefficient & $.79 * *$ & $.83^{* *}$ & $.88 * *$ & $* *$ & 1 \\
\hline & Sig. (2-tailed) & .00 & .00 & .00 & . & - \\
\hline
\end{tabular}

Note. ${ }^{* *}$ Correlation is significant at the 0.05 level (2-tailed). Source. Survey Data, 2019.

\section{Discussion of findings and conclusion}

The first hypothesis which states that family structure has no significant effect on profitability of SMEs, was statistically tested and result indicated that family structure has a positive and strong correlation $(\mathrm{rs}=0.84, p<.05)$ with profitability. This implies that the profitability of SMEs is enhanced especially where family structure of the entrepreneur is traditionally rooted. The second hypothesis which evaluated the relationship between family structure and survival revealed a correlation value of 0.79 . This entails a positive and significant relationship between both variables; consequently, entrepreneurs from good family structure have a possibility sustainable survival in business. In the same vein, hypothesis three which states that there is no significant relationship between communal spirit and profitability of SMEs was statistically tested, and result indicates a positive and strong correlation (of $\mathrm{rs}=0.93$ ) between both variables. This practically entail that entrepreneur with strong communal spirit has a high possibility of increasing profitability of their enterprise despite stiff competition among SMEs. Further, hypothesis four was tested and result showed a positive and significant correlation (rs=0.88) between communal spirit and survival. Lastly, a positive but weak correlation exists between individual orientation and entrepreneurial performance of SMEs. This was particularly revealed after testing hypotheses five and six ( $r s=0.42$ and 0.44). In real business situation entrepreneurs with individualism orientation may find it difficult to enhance performance because such orientation will result profitability and growth.

\section{Conclusion}

It is evident that learned traits from different cultures in Nigeria affect individual behavior and impact on entrepreneurial skills, performance and development. Herein lays the importance of cultural values and orientation 
in helping entrepreneurs grow and survive in business. Based on the findings, cultural identity such as family structure and communal spirit has a positive and significant influence on entrepreneurial performance of SMEs in Delta State. However, individualism orientation has a positive but weak relationship with entrepreneurial performance. In view of the findings and conclusion, the study recommends that entrepreneurs or owners of SMEs should endeavor to adopt a collaborative orientation thereby involving key stakeholders in decision making and addressing challenges collectively rather than as individuals. This will be particularly relevant in managing the burden of high energy costs being borne by SMEs. Furthermore, policies to encourage entrepreneurial partnerships across cultural group-persons from entrepreneurially-weak cultures to partner with individuals from entrepreneurially-strong cultures. Such a policy, if well-implemented, will be effective towards increasing the sustainability of SMEs in Delta State and ensuring inclusive growth. It may, however, be more interesting to compare entrepreneurial attitudes and the performance of SMEs across different regions of Nigeria.

\section{References}

Ahmed, T., Chandran, V., \& Klobas, J. (2017). Specialized entrepreneurship education: does it really matter? Fresh evidence from Pakistan. International Journal of Entrepreneurial Behavior \& Research, 23(1), 4-19. https://doi.org/10.1108/IJEBR-01-2016-0005

Ajekwu, C. (2017). Effect of culture on entrepreneurship in Nigeria. International Journal of Business and Management Invention, 6(2), 1-6.

Akanmu, P. M., Alhaji, S. A., Kowo Solomon Akpoviroro, A., \& Ajani, O. (2018). Effect of cultural orientation on entrepreneurial cluster initiatives in Kwara State Nigeria. International Journal of Advance Research and Innovative Ideas in Education, 4(3), 768-777.

Akpor-Robaro, M. O. M. (2012). The impact of socio-cultural environment on entrepreneurial emergence: A theoretical analysis of Nigerian society. European Journal of Business and Management, 4(16), 172-182.

Aldrich, H. E., \& Cliff, J. E. (2003). The pervasive effects of family on entrepreneurship: Toward a family embeddedness perspective. Journal of business venturing, 18(5), 573-596. https://doi.org/10.1016/S0883-9026(03)00011-9

Barnett, T., Eddleston, K., \& Kellermanns, F. W. (2009). The effects of family versus career role salience on the performance of family and nonfamily firms. Family Business Review, 22(1), 39-52. https://doi.org/10.1177/0894486508328814

Bjursell, C., \& Bäckvall, L. (2011). Family business women in media discourse: The business role and the mother role. Journal of Family Business Management, 1(2), 154-173. https://doi.org/10.1108/20436231111167228

Block, Z., \& Stumpf, S. A. (1990). Entrepreneurship education research: experience and challenge. New York: Center for Entrepreneurial Studies, New York University, Leonard N. Stern School of Business.

Chandler, G. N., \& Hanks, S. H. (1993). Measuring the performance of emerging businesses: A validation study. Journal of business venturing, 8(5), 391-408. https://doi.org/10.1016/0883-9026(93)90021-V

Chrisman, J. J., Chua, J. H., Pearson, A. W., \& Barnett, T. (2012). Family involvement, family influence, and family-centered non-economic goals in small firms. Entrepreneurship Theory and Practice, 36(2), 267-293. https://doi.org/10.1111/j.1540-6520.2010.00407.x

Combs, J. G., Russell Crook, T., \& Shook, C. L. (2005). The dimensionality of organizational performance and its implications for strategic management research. In D. Ketchen, J. \& D. D. Bergh (Eds.), Research methodology in strategy and management (Research Methodology in Strategy and Management (Vol. 2, pp. 259-286). Bingley, United Kingdom: Emerald Group Publishing Limited. https://doi.org/10.1016/S1479-8387(05)02011-4

Covin, J. G., Green, K. M., \& Slevin, D. P. (2006). Strategic process effects on the entrepreneurial orientation-sales growth rate relationship. Entrepreneurship Theory and Practice, 30(1), 57-81. https://doi.org/10.1111/j.1540-6520.2006.00110.x

Deakins, D., \& Freel, M. S. (2012). Entrepreneurship and small firms. London; Boston McGraw-Hill Higher 
A cultural identity perspective of entrepreneurial performance of small firms

Education.

Ejemeyovwi, J., Obindah, G., \& Doyah, T. (2018). Carbon dioxide emissions and crop production: Finding a sustainable balance. International Journal of Energy Economics and Policy, 8(4), 303-309.

Eniola, A. A. (2018). SME firm characteristics impact on the choice of sources of financing in South-West, Nigeria. International Journal of Business and Globalisation, 21(3), 344-366. https://doi.org/10.1504/IJBG.2018.095482

Eniola, A. A., \& Entebang, H. (2015). Government policy and performance of small and medium business management. International Journal of Academic Research in Business and Social Sciences, 5(2), 237-248. https://doi.org/10.6007/IJARBSS/v5-i2/1481

Ezirim, B. C. (2004). Dimensions of financial management and policy. Port Harcourt, Nigeria: Markowitz Centre for Research and Development.

Fong, M., \& Chuang, R. (2004). Communicating ethnic and cultural identity. Lanham, MD: Rowman \& Littlefield Publishers.

Gershon, O., \& Ezurum, A. (2017). Energy sector governance and cost reflective pricing in West Africa. Paper presented at the 12th African Economic Conference, Addis Ababa, Ethiopia.

Gibb, A. A. (1987). Enterprise culture: Its meaning and implications for education and training. Journal of European Industrial Training, 11(2), 2-38. https://doi.org/10.1108/eb043365

Gibb, A. A. (1996). Entrepreneurship and small business management: Can we afford to neglect them in the twenty-first century business school? British Journal of management, 7(4), 309-321. https://doi.org/10.1111/j.1467-8551.1996.tb00121.x

Haapaniemi, T. P., \& Mäkinen, S. J. (2008). Moderating effect of national attributes and the role of cultural dimensions in technology adoption takeoff. Management Research News, 32(1), 5-25. https://doi.org/10.1108/01409170910921998

Harknett, K. (2005). Children's elevated risk of asthma in unmarried families: Underlying structural and behavioral mechanisms. Working Paper. Center for Research on Child Wellbeing. Robert Wood Johnson Foundation (RWJF). University of Pennsylvania. Retrieved from https://core.ac.uk/download/pdf/6885423.pdf

Harrison, L. E., \& Huntington, S. P. (2006). Culture matters: How values shape human progress. New York: Basic Books.

Hofstede, G. (2001). Culture's consequences: comparing values, behaviour, institutions \& organizations across nations (2nd ed.). Tilburg University, Netherlands: Sage Publication.

Hofstede, G. (2002). Dimensions do not exist: A reply to Brendan McSweeney. Human Relations, 55(11), 1355-1361. https://doi.org/10.1177/0018726702055011921

Hofstede, G. (2006). What did GLOBE really measure? Researchers' minds versus respondents' minds. Journal of International Business Studies, 37(6), 882-896. https://doi.org/10.1057/palgrave.jibs.8400233

Ibrahim, F. A., \& Heuer, J. R. (2013). The assessment, diagnosis, and treatment of mental disorders among Muslims. In F. A. Paniagua \& A.-M. Yamada (Eds.), Handbook of multicultural mental health (2nd ed., pp. 367-387). San Diego: Academic Press. https://doi.org/10.1016/B978-0-12-394420-7.00019-9

Imm Ng, S., Anne Lee, J., \& Soutar, G. N. (2007). Are Hofstede's and Schwartz's value frameworks congruent? International Marketing Review, 24(2), 164-180. https://doi.org/10.1108/02651330710741802

Jameson, D. A. (2007). Reconceptualizing cultural identity and its role in intercultural business communication. The Journal of Business Communication (1973), 44(3), 199-235. https://doi.org/10.1177/0021943607301346

Javidan, M., House, R. J., Dorfman, P. W., Hanges, P. J., \& Sully de Luque, M. (2006). Conceptualizing and measuring cultures and their consequences: a comparative review of GLOBE's and Hofstede's approaches. Journal of International Business Studies, 37(6), 897-914. https://doi.org/10.1057/palgrave.jibs.8400234

Kellermanns, F. W., Eddleston, K. A., Barnett, T., \& Pearson, A. (2008). An exploratory study of family member characteristics and involvement: Effects on entrepreneurial behavior in the family firm. Family Business Review, 21(1), 1-14. https://doi.org/10.1111/j.1741-6248.2007.00107.x 
Eniola, A. A., Ojo, O. R., \& Ajala, A. B.

Kim, Y. Y. (2007). Ideology, identity, and intercultural communication: An analysis of differing academic conceptions of cultural identity. Journal of Intercultural Communication Research, 36(3), 237-253. https://doi.org/10.1080/17475750701737181

Kuratko, D. F., \& Hodgetts, R. M. (2001). Entrepreneurship: A contemporary approach. Fort Worth: Harcourt College Publishers.

Liang, C.-L., \& Dunn, P. (2010). Entrepreneurial characteristics, optimism, pessimism, and realism: Correlation or collision. Journal of Business and Entrepreneurship, 22(1), 1-22.

Miike, Y. (2002). Theorizing culture and communication in the Asian context: An assumptive foundation. Intercultural Communication Studies, 11(1), 1-22.

Mokomane, Z. (2012, 10-12 September 2012). Role of families in social and economic empowerment of individuals. Paper presented at the United nations expert group meeting on Promoting empowerment of people in achieving poverty eradication, social integration and full employment and decent work for all, United Nations, New York.

Oluwatobi, S., Olurinola, I., Alege, P., \& Ogundipe, A. (2018). Knowledge-driven economic growth: The case of Sub-Saharan Africa. Contemporary Social Science, 1-20. https://doi.org/10.1080/21582041.2018.1510135

Onodugo, V., \& Onodugo, C. I. (2015). Impact of socio-cultural factors on entrepreneurial development in Nigeria. African Educational Research Journal, 3(4), 246-254.

Peppas, S. C., Yu, T. T., Zhang, M. M., \& Peppas, S. R. (2017). Student perceptions of codes of ethics: A three-country comparison. International Journal of Economics and Business Research, 13(1), 43-56. https://doi.org/10.1504/IJEBR.2017.081775

Rao, P. (2009). The role of national culture on Mexican staffing practices. Employee Relations, 31(3), $295-311$. https://doi.org/10.1108/01425450910946488

Rogoff, E. G., \& Heck, R. K. Z. (2003). Evolving research in entrepreneurship and family business: Recognizing family as the oxygen that feeds the fire of entrepreneurship. Journal of business venturing, 18(5), 559-566. https://doi.org/10.1016/S0883-9026(03)00009-0

Shane, S., \& Venkataraman, S. (2000). The promise of entrepreneurship as a field of research. Academy of Management Review, 25(1), 217-226. https://doi.org/10.5465/amr.2000.2791611

Swierczek, F. W., \& Ha, T. T. (2003). Entrepreneurial orientation, uncertainty avoidance and firm performance: an analysis of Thai and Vietnamese SMEs. The International Journal of Entrepreneurship and Innovation, 4(1), 46-58. https://doi.org/10.5367/000000003101299393

Thomas, A. S., \& Mueller, S. L. (2000). A case for comparative entrepreneurship: Assessing the relevance of culture. Journal of International Business Studies, 31(2), 287-301. https://doi.org/10.1057/palgrave.jibs.8490906

Utomi, P. O. (2000). Critical perspectives on Nigerian political economy and management: A book of readings and cases in social and political environment of business. Ibadan, Nigeria: Spectrum Books Limited.

Van De Ven, H. (1993). The development of an infrastructure for entrepreneurship. Journal of business venturing, 8(3), 211-230. https://doi.org/10.1016/0883-9026(93)90028-4

Wiklund, J., \& Shepherd, D. (2005). Entrepreneurial orientation and small business performance: A configurational approach. Journal of business venturing, 20(1), 71-91. https://doi.org/10.1016/j.jbusvent.2004.01.001

World Bank. (2014). Doing business 2015: Going beyond efficiency. Retrieved from https://openknowledge.worldbank.org/handle/10986/20483 